\title{
Study of the chemical composition, proteolysis, volatile compounds, and textural properties of industrial and traditional Beaten (Bieno sirenje) ewe milk cheese
}

\author{
E. Sulejmani, ${ }^{*}{ }^{1}$ A. A. Hayaloglu, $\dagger$ and V. Rafajlovskał \\ *Department of Food Technology and Nutrition, State University of Tetova, 1200, Tetovo, Republic of Macedonia \\ †Department of Food Engineering, Inonu University, 44280 Malatya, Turkey \\ łDepartment of Food Technology and Biotechnology, Ss. Cyril and Methodius University in Skopje, 1000 Skopje, Republic of Macedonia
}

\begin{abstract}
The objective of this study was to determine the gross composition, proteolysis, and volatile and texture profiles during ripening of industrial (IND) and traditional (TRD) Beaten (Bieno sirenje) cheeses made by using ewe milk. In the course of the analyses, statistical differences were determined in some physicochemical parameters, nitrogen fractions, and total free amino acid levels between TRD and IND types of cheese. Higher levels of proteolysis were observed in IND cheeses than in TRD cheeses during ripening. Levels of residual $\beta$ - and $\alpha_{\mathrm{s}}$-caseins were 72.2 and $48.7 \%$, respectively, in 180-d-old TRD cheeses. However, the residual levels were $52.8 \%$ for $\beta$-casein and $18 \%$ for $\alpha_{\mathrm{s}}$-casein in IND cheeses. Similar differences were noted for the reversedphase HPLC peptide profiles of 2 types of cheeses. Also, higher concentrations of peptides were eluted in IND cheeses than in TRD cheeses during ripening. A total of 73 volatile compounds, including alcohols (16), esters (17), acids (14), terpenes (7), ketones (5), aldehydes (4), and miscellaneous (10) were identified. The IND cheeses contained higher levels of carboxylic acids, esters, alcohols, and terpenes than the TRD cheeses; however, the same levels of methyl ketones were determined in the 2 types of cheeses at the end of ripening. These may be due to some differences (e.g., pasteurization and scalding temperature, among other factors) in the manufacture of the 2 types of Beaten cheeses. The textural profile of Beaten cheeses showed that TRD production method resulted in firmer, less fracturable, and stiffer cheeses than the IND production method. In conclusion, the results suggest that the use of industrial production method (pasteurization of cheese milk and curd scalding at $70^{\circ} \mathrm{C}$ ) in the manufacture of Beaten ewe milk cheese enriched the volatile profile of the cheese.
\end{abstract}

Received June 2, 2013.

Accepted October 23, 2013

${ }^{1}$ Corresponding author: erhan.sulejmani@unite.edu.mk
Key words: Bieno sirenje, volatiles, proteolysis, textural properties

\section{INTRODUCTION}

The unique flavor of a cheese variety is the result of a complex balance among volatile and nonvolatile chemical compounds, originating during the ripening process from milk fat, protein, and carbohydrates (Fox and Wallace, 1997). In addition, the use of raw milk in production enhances the volatiles in cheese, especially acids, alcohols, and esters, due to the heat treatment of milk inactivating enzymes and microorganisms present in milk, which are related to the formation of aroma compounds (Hayaloglu and Brechany, 2007). Proteolysis is the most complex and perhaps the most important of the 3 primary biochemical events that occur during ripening. In most varieties, the caseins are initially hydrolyzed by enzymes from the coagulant and, to a lesser extent, from the milk (plasmin and perhaps somatic cell proteinases); thus, it forms large and intermediatesized peptides (McSweeney, 2004). The hydrolysis of $\beta-\mathrm{CN}$ by chymosin is strongly inhibited by $5 \%$ (wt/ vol) $\mathrm{NaCl}$ and completely inhibited by $10 \%, \mathrm{NaCl}$ (Fox and Walley, 1971). Due to the high salt-in-moisture ratio in matured Beaten cheese, the level of proteolysis is limited during maturation (Dubrova Mateva et al., 2008). Residual coagulant retained in the curd is the major source of proteolytic activity in most cheeses, except in pasta filata varieties and those with a high cooking temperature. In those cheeses, the enzymes of residual coagulant are denatured extensively by cooking (Boudjellab et al., 1994) and weakly contribute to the proteolysis.

Beaten cheese (Bieno sirenje) is a traditional autochthonous type of cheese produced in Macedonia and other Balkan countries with relatively high nutritional value and performance characteristics. The cheeses ripened under brine in the Balkan Peninsula and Mediterranean countries were extensively listed and discussed by Alichanidis and Polychroniadou (2008). It is traditionally 
made using raw ewe or cow milk, or mixtures thereof, where no starter is added. It is the third most popular cheese in Macedonia and the production volume of Beaten cheese has increased recently. According to the Macedonian Statistical Department (http://www.stat. gov.mk/Publikacii/6.4.13.01.pdf), the production value of hard cheeses, including Beaten cheese, was 3,858 t in 2012 compared with $3,166 \mathrm{t}$ in 2010 , representing an increase of $18 \%$.

The traditional cheese-making procedure is still used in farms and villages. The scalding procedure is a crucial step in Beaten cheese manufacture and substantially affects the physical, biochemical, and sensory properties of the cheese (Dubrova Mateva et al., 2008). This name was given upon the manufacturing process of the cheese: the cheese curd is beaten; therefore, it is called "Beaten cheese" and also "Bieno sirenje." The heating process in the manufacturing of Beaten cheese is similar to the one that is applied in the manufacture of Halloumi types of cheese. Beaten cheese is hard and contains a high level of fat with spongy appearance, and it ripens in brine. Great diversity exists in the manufacturing procedures of Beaten cheese, which implies a lack of standardization in its manufacture (Talevski, 2012).

We hypothesized that some differences would exist in the quality of Macedonian Beaten cheeses made by traditional (TRD) or industrial (IND) methods. To our knowledge, no information is available on the reversedphase HPLC (RP-HPLC) peptide profile, urea-PAGE patterns of caseins, and volatile profiles of Beaten cheese during ripening. However, some traditional ewe milk cheeses have been characterized with respect to RPHPLC peptide profile, urea-PAGE patterns of caseins, and volatile compounds during ripening (Pinho et al., 2004; Pintado et al., 2008). The novelty of this work is to investigate the effects of different production methods (IND or TRD) on proteolysis, volatile compounds, and peptide and texture profiles of Macedonian Beaten cheese during ripening.

\section{MATERIALS AND METHODS}

\section{Cheese Manufacture and Sampling}

Raw ewe milk (supplied in Tetovo, Republic of Macedonia) was used in the manufacture of Beaten cheese by the TRD method. The quality characteristics of the milk were determined by standard analytical methods (Ardö and Polychroniadou, 1999). The chemical composition of the milk used in the manufacture of Beaten cheeses was 19.96\% TS, 7.55\% fat, $6.17 \%$ protein, $0.71 \%$ ash, and $5.53 \%$ lactose. The $\mathrm{pH}$ of the milk was 6.20 . Beaten cheesemaking was performed in duplicate by the IND method in a local dairy plant (Eko Sharr, Poroj Village, Tetovo, Republic of Macedonia) and the TRD method in Vejce Village (Tetovo, Republic of Macedonia). Raw ewe milk was pasteurized at $65^{\circ} \mathrm{C}$ for $10 \mathrm{~min}$ for IND Beaten cheese and yogurt cultures containing Streptococcus thermophilus and Lactobacillus delbrueckii ssp. bulgaricus were used as starter. The acidified milk was coagulated by using commercial non-animal rennet (CHY-MAX Liquid Plus; Chr. Hansen, Hørsholm, Denmark) at a level of $20 \mathrm{~mL} / 100 \mathrm{~L}$. Raw ewe milk was used for the manufacture of TRD Beaten cheese and it was coagulated by using animal rennet (NATUREN; Chr. Hansen) at a level of $20 \mathrm{~mL} / 100 \mathrm{~L}$. The milk was allowed to coagulate at $34^{\circ} \mathrm{C}$ for 45 min. Following the coagulation, IND cheese curd was mechanically stirred and beaten 40 to 50 times with a special metal tackle (horizontally and vertically knitted metal wires) for about $5 \mathrm{~min}$, and then left for 30 min to facilitate whey drainage. The TRD cheese curd was stirred and beaten manually with a wooden stick until a homogenous compact structure was obtained. After the drainage, the curd was cooked in hot water to $70^{\circ} \mathrm{C}$ (IND) and $90^{\circ} \mathrm{C}$ (TRD) for $20 \mathrm{~min}$. Following the cooking, the curd was again beaten for 2 to $3 \mathrm{~min}$ (IND) and 5 to $10 \mathrm{~min}$ (TRD) and then left to rest for 15 to $20 \mathrm{~min}$. Following the rest period, the curd was molded into balls, which were then transferred to a cotton cloth for hanging by its own weight (IND) or by a weight pressure of $3 \mathrm{~kg} / \mathrm{kg}$ (TRD) for about $24 \mathrm{~h}$. Then, the curd was preripened for $3 \mathrm{~d}$ at $35^{\circ} \mathrm{C}$ (IND) and in sunlight (TRD). During this period, the curd gained a specific yellowish color due to the proportional increase of $\beta$-carotene among casein micelles. Then, the cheese loafs were cut in slices 30 to $40 \mathrm{~cm}$ long and 4 to $5 \mathrm{~cm}$ wide. The cheese blocks were salted by dry-salting for $24 \mathrm{~h}$ and then brine salting. The pieces were collected and packed in plastic barrels containing brine with a concentration of 18 to $20 \%$ (wt/vol) $\mathrm{NaCl}$ for long-term storage. The barrels contained a sufficient quantity of brine for immersion of cheeses. The cheeses were ripened for $180 \mathrm{~d}$ in brine at $6 \pm 1^{\circ} \mathrm{C}$ and samples were taken after 15, 30, 60, 90, 120, 150, and $180 \mathrm{~d}$ of ripening. Two cheese-making trials were carried out for the manufacture of Beaten cheese.

\section{Cheese Analysis}

Cheese samples were analyzed in duplicate for moisture, fat, salt, $\mathrm{pH}$, titratable acidity (as percentage of lactic acid), and total nitrogen by the methods described by Ardö and Polychroniadou (1999). Also, proteolysis and volatile compounds profiles and texture were determined. 
Proteolysis. Total nitrogen (TN) content was estimated by the Kjeldahl method (IDF, 1993) using a Kjeldahl device (model DS1; ŞimŞek Laborteknik, Ankara, Turkey). The water-soluble nitrogen (WSN) and $12 \%$ TCA-soluble nitrogen (TCA-SN) as percentage of TN and total free amino acid (FAA) of the cheeses were determined by the methods described by Hayaloglu (2007). The water-insoluble fractions of the cheeses were freeze-dried and then analyzed by ureaPAGE using a Protean II XI vertical slab gel unit (Bio-Rad Laboratories Ltd., Watford, UK) according to the method of Andrews (1983) and the gels were stained directly by the method of Blakesley and Boezi (1977) with Coomassie brilliant blue G-250 dye. After destaining using pure water, gel slabs were digitized using a scanner (HP Scanjet software, Scanjet G4010; Hewlett-Packard, Palo Alto, CA). Scans of the electrophoretograms were used to quantify bands using densitometric software (ImageMaster TotalLab Phoretix 1D Pro software; Keel House, Newcastle upon Tyne, UK). The caseins and peptides were determined quantitatively by integration of peak volumes and areas using the densitometer. The WSN fractions of the cheeses were also freeze-dried for determination of peptide profiles. The analysis were realized by RP-HPLC described by Hayaloglu et al. (2011) using a Shimadzu LC 20 AD Prominence HPLC system (Shimadzu Corp., Kyoto, Japan).

Solid-Phase Microextraction/GC-MS Analysis of Volatiles. Analysis of the volatiles were performed by a static solid-phase microextraction method described by Hayaloglu et al. (2013), using a GC-MS system (Shimadzu Corp.). The identifications were based on comparing mass spectra of unknown compounds with those in the mass spectral library of John Wiley and Sons Inc. (2005) and the National Institute of Standards and Technology/Environmental Protection Agency/National Institutes of Health (NIST/EPA/NIH 02; http://www.nist.gov/srd/nist1a. cfm) mass spectral library. Identifications were also confirmed by comparing retention times with reference standards when available. A total of 33 authentic standard compounds (Sigma Chemical Co., St. Louis, $\mathrm{MO}$ ) were used to confirm the identities of volatile compounds in the cheese samples. The concentrations were calculated by the comparison of the peak areas of the internal standard containing an $81 \mathrm{mg} / \mathrm{kg}$ mixture of 2-methyl-3-heptanone and 2-methyl-1-pentanoic acid in methanol (Sigma-Aldrich Co.) and unknown compounds. Each compound was expressed in micrograms per $100 \mathrm{~g}$ of cheese.

Texture Analysis. Texture of industrial and traditional Beaten cheese during ripening was determined by compression testing with Texture Analyzer Model LF
Plus (Lloyd Instruments Ltd., Fareham, UK) in triplicate. Cheese samples with $10-\mathrm{mm}$ height and $20-\mathrm{mm}$ diameter were used for the test at $20^{\circ} \mathrm{C}$. Samples were tested using an aluminum probe with 25-mm diameter; the test speed and compression were $50 \mathrm{~mm} / \mathrm{min}$ and $25 \%$, respectively. Data collection and calculation were done by using NEXYGEN FM Software (Lloyd Instruments Ltd.).

\section{Statistical Analysis}

A randomized complete block design, which incorporated 2 treatments (TRD or IND cheeses), 8 ripening periods $(15,30,60,90,120,150$, or $180 \mathrm{~d})$, and 2 blocks (trials) was used to analyze the response variables related to cheese composition, proteolysis, and volatiles data. Analysis of variance was performed using a general linear model procedure (SAS Institute, 1995), where the effect of treatment and replicates were estimated for response variables. The Tukey multiple-comparison test was used as a guide for pair comparisons of treatment means. The level of significance of differences between treatments was considered at $P<0.05$.

\section{RESULTS AND DISCUSSION}

\section{Chemical Composition}

The gross chemical compositions of the IND and TRD Beaten cheeses during ripening are presented in Table 1. The fat, salt, and protein contents, and lactic acid value of the Beaten cheese samples at d 15 of ripening were significantly different; however, the moisture content and $\mathrm{pH}$ value were similar. The gross chemical composition and $\mathrm{pH}$ values of the cheeses made by using the TRD and IND methods of manufacturing were significantly affected by manufacturing method during ripening, as shown in Table $1(P<0.05)$. The $\mathrm{pH}$ of the cheese at the end of ripening was around 5.2 and the value is in accordance with that of Beaten cheese reported by Dubrova Mateva et al. (2008). The $\mathrm{pH}$ values decreased gradually during ripening in both types of cheeses and showed minor differences $(P<0.05)$. The levels of protein and fat contents were higher in TRD cheeses than in IND cheeses during ripening. The values for protein and fat levels were in accordance with the findings of Dubrova Mateva and Srbinovska (2010). The level of moisture was lower in TRD cheeses than in IND cheeses. The concentration effect of total solid substances caused higher levels of protein and fat in the TRD cheeses. Salt contents of the cheeses ranged from 5.2 to $6.9 \%$ (TRD) and 6.8 to $8.6 \%$ (IND). During the maturation of the cheeses, the chemical composition of the cheese changed dramatically; the moisture contents 
increased, whereas the salt contents decreased proportionally. The salt-in-moisture ratio in matured IND Beaten cheese was significantly higher than in TRD Beaten cheese, which was similar to Halloumi cheese (Papademas, 2000). The lactic acid content of cheese increased gradually during ripening in both types of Beaten cheeses (Table 1).

\section{Proteolysis}

The mean values of WSN and $12 \%$ (wt/vol) TCA-SN (expressed as percentage of TN) from Beaten cheeses are presented in Figure 1. The levels of WSN and TCA$\mathrm{SN}$ in the cheeses increased during ripening; however, the rate of increase was not intense at the beginning of the ripening period (until d 60). Similar to other brined cheeses, the nitrogenous substances increased during the ripening period and, after reaching a maximum level, they decreased due to the effect of leaching into the brine (Abd El-Salam and Alichanidis, 2004). The levels of WSN in IND and TRD Beaten cheeses showed significant differences during ripening $(P<$ 0.05). Pintado et al. (2008) reported great variability in proteolysis of traditional ewe milk cheeses. The great variability in proteolysis of traditional cheeses is due to variability in microbiological content; however, the high scalding temperature of TRD method may reduce the importance of microbiota. The majority of brineripened cheeses have low $\mathrm{pH}$ and high moisture values and these conditions are favorable for the activity of chymosin on $\alpha_{\mathrm{s} 1}-\mathrm{CN}$, resulting in rapid increases of soluble nitrogen (Hayaloglu et al., 2005). After $15 \mathrm{~d}$ of ripening, IND cheeses had higher levels of WSN than TRD cheeses; the highest WSN values were registered at d 120 of ripening and then declined again. However, the levels of WSN were higher in IND cheeses than in TRD cheeses $(P<0.05)$. The differences may be due to the different rates of residual coagulant in the 2 cheeses, as a consequence of the different processing conditions, especially the cooking temperature, in which the coagulant is extensively denatured by the high cooking temperature (Farkye and Fox, 1990). Also, it was reported that thermal inactivation of residual rennet by high scalding temperatures slowed down the proteolysis in Malatya cheese (Hayaloglu and Brechany, 2007). The total FAA content (given as milligrams of Leu per gram of cheese) increased in the cheeses during ripening, with substantial differences that were observed between the 2 types (TRD and IND) of cheeses (Table 1 ). The total FAA contents were the highest in the IND cheeses, probably due to lower scalding temperature used in manufacturing compared with TRD method. The level of total FAA reached $1.48 \mathrm{mg}$ of Leu/g of cheese on d 180 in IND cheeses; however, it was $1.18 \mathrm{mg}$ of Leu/g

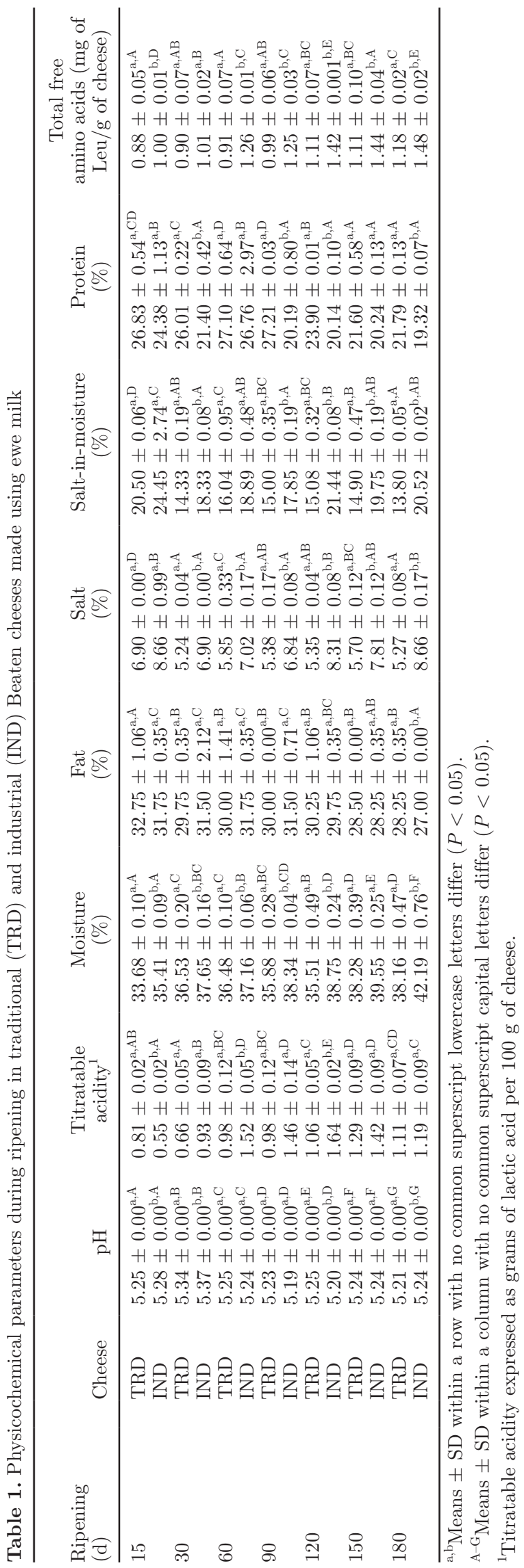

Journal of Dairy Science Vol. 97 No. 3, 2014 


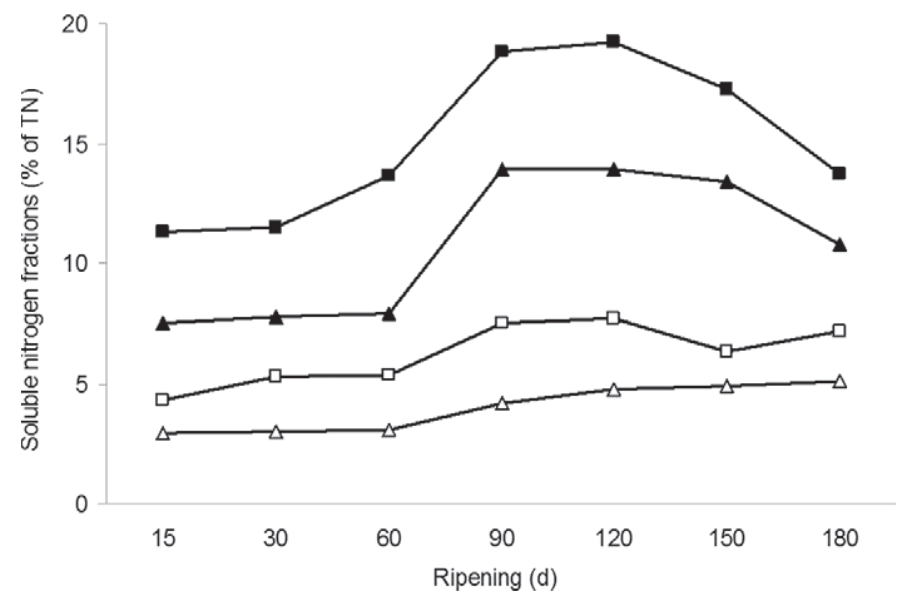

Figure 1. Levels of water-soluble nitrogen (WSN; solid symbols) and $12 \%$ TCA-soluble nitrogen (TCA-SN; open symbols) fractions in traditional (TRD) and industrial (IND) Beaten ewe milk cheese during $180 \mathrm{~d}$ of ripening. These 2 fractions were expressed as percentage of total nitrogen (TN). Square and triangle symbols represent cheeses made by IND and TRD methods, respectively.

of cheese for TRD cheeses during the same sampling time. The level of total FAA in Beaten cheeses showed a similar trend to the soluble nitrogen fractions, including WSN-SN, during ripening, as reported by other researchers (Hayaloglu, 2007; Andiç et al., 2010).

Urea-PAGE patterns of the cheeses and the evaluation of these bands are shown in Figure 2. The hydrolysis of individual casein fractions was expressed as a percentage of the concentration of the corresponding casein present at $15 \mathrm{~d}$ of ripening (Table 2). The residual $\alpha_{\mathrm{s}^{-}}$and $\beta$-CN in both cheeses continuously decreased during ripening $(P<0.05)$. The breakdown of $\alpha_{\mathrm{s}}{ }^{-} \mathrm{CN}$ was $(P<0.05)$ slower in traditional Beaten cheese during ripening (Table 2). Similarly, significant differences were determined between the 2 Beaten cheeses regarding the degradation of $\beta$-CN during the $180 \mathrm{~d}$ of ripening $(P<0.05)$. It is evident that the rate of degradation of $\alpha_{\mathrm{s}}-\mathrm{CN}$ was higher than that of $\beta-\mathrm{CN}$ (Mallatou et al., 2004). In the present study, about $82 \%$ of the $\alpha_{\mathrm{s}} \mathrm{CN}$ originally present was degraded in the IND cheeses at $180 \mathrm{~d}$ of ripening, but only $51 \%$ of the $\alpha_{\mathrm{s}}-\mathrm{CN}$ was degraded in the TRD cheeses at the same period of aging. On the other hand, about 47 and $28 \%$ of the $\beta-\mathrm{CN}$ originally present was degraded in the cheeses made according to the IND and TRD methods, respectively, at $180 \mathrm{~d}$ of ripening. The lower rate of degradation of the $\beta-\mathrm{CN}$ compared with $\alpha_{\mathrm{s}}-\mathrm{CN}$ may be attributed to the structure of $\beta$-CN, which renders the molecule less accessible to enzymes (Phelan et al., 1973). However, degradation of $\alpha_{\mathrm{s}^{-}}$and $\beta-\mathrm{CN}$ were noticeably faster in IND cheese than in TRD cheeses due to the lower cooking temperature used in the manufacture of
IND cheese (which contains a higher amount of residual chymosin), which indicates denaturation of chymosin during cooking (Farkye and Fox, 1990). This indicates that the cooking temperature has a major effect on the level of residual rennet in the curd; chymosin and bovine pepsin are extensively or totally denatured in high-temperature-cooked cheese (e.g., Parmigiano-Reggiano and Emmental cheese). A slow degradation rate of $\beta$-CN was observed in other brine-ripened cheeses (Katsiari et al., 2000; Hayaloglu et al., 2010). Karagul Yuceer et al. (2009) investigated the level of proteolysis in Ezine cheeses by using urea-PAGE analysis, which showed that $\alpha_{s}-C N$ degraded very quickly; however, $\beta$-CN breakdown was almost constant. The hierarchical cluster analysis of the gels showed that cheeses grouped by age and manufacturing method (Figure 2); however, the effect of age on the casein degradation was greater than those of manufacturing methods (IND or TRD). Two big clusters appeared on the dendrogram (Figure 2 ): the younger cheeses positioned together (left) and the older cheeses grouped together (right).

The RP-HPLC peptide profiles of the water-soluble fractions of the cheeses are presented in Figures 3a and $3 \mathrm{~b}$. Some differences were observed during ripening for the fractions of peptides, which were eluted in IND cheeses at higher levels than in TRD cheeses. Increases were observed in the concentrations of peptides that mainly eluted between min 20 and 40 in the IND cheeses. In the chromatogram, between min 60 and 66 , the peak heights in TRD cheeses were generally much higher than in IND cheeses. In the case of the TRD cheeses, the particular peaks with retention time between 22 to 26 min appeared and varied strongly, depending on the type of cheese and ripening process. However, the pattern and extent of proteolysis varied due to differences in the manufacturing practices (IND and TRD methods), which caused differences in the moisture content and residual coagulant activity. Peaks corresponding to small hydrophilic peptides (retention time $<15 \mathrm{~min})$ were already detectable in all cheeses (IND and TRD). Peaks that appeared at a retention time of 60 to 69 min corresponded to large hydrophobic peptides, which are strongly correlated with the bitterness of cheeses (Bumberger and Belitz, 1993), and were higher mostly in the IND cheeses. The bitter peptides in cheese appear to originate primarily from $\beta-\mathrm{CN}$ (Frister et al., 2000), which might be expected, as $\beta$-CN is the most hydrophobic casein (Swaisgood, 2003). The TRD cheeses could be characterized by smaller peaks in the hydrophobic peptide zone (retention time of 60 to $66 \mathrm{~min}$ ), which is in accordance with other brine-type cheeses, such as Feta cheese (Michaelidou-Koniordou, 1997). 
Table 2. Residual $\alpha_{\mathrm{s}}-\mathrm{CN}$ and $\beta$-CN in industrial (IND) and traditional (TRD) Beaten cheeses during ripening ${ }^{1}$

\begin{tabular}{|c|c|c|c|c|}
\hline \multirow[b]{2}{*}{ Ripening (d) } & \multicolumn{2}{|c|}{ Residual $\alpha_{\mathrm{s}}-\mathrm{CN}(\%)$} & \multicolumn{2}{|c|}{ Residual $\beta$-CN (\%) } \\
\hline & IND & TRD & IND & TRD \\
\hline 15 & 100 & 100 & 100 & 100 \\
\hline 30 & $58.6 \pm 2.09^{\mathrm{a}}$ & $59.0 \pm 3.12^{\mathrm{b}}$ & $96.8 \pm 0.55^{\mathrm{a}}$ & $97.2 \pm 1.07^{\mathrm{a}}$ \\
\hline 60 & $52.9 \pm 2.14^{\mathrm{a}}$ & $56.4 \pm 0.34^{\mathrm{b}}$ & $69.4 \pm 1.21^{\mathrm{a}}$ & $93.1 \pm 0.22^{b}$ \\
\hline 90 & $39.2 \pm 0.87^{\mathrm{a}}$ & $53.9 \pm 1.22^{\mathrm{b}}$ & $69.4 \pm 0.66^{\mathrm{a}}$ & $76.4 \pm 2.71^{\mathrm{b}}$ \\
\hline 120 & $28.0 \pm 2.79^{\mathrm{a}}$ & $52.6 \pm 0.44^{\mathrm{b}}$ & $65.3 \pm 3.12^{\mathrm{a}}$ & $72.2 \pm 1.92^{\mathrm{b}}$ \\
\hline 150 & $18.0 \pm 1.68^{\mathrm{a}}$ & $52.6 \pm 1.32^{\mathrm{b}}$ & $59.7 \pm 1.09^{\mathrm{a}}$ & $72.2 \pm 2.17^{\mathrm{b}}$ \\
\hline 180 & $18.0 \pm 1.01^{\mathrm{a}}$ & $48.7 \pm 2.44^{\mathrm{b}}$ & $52.8 \pm 2.90^{\mathrm{a}}$ & $72.2 \pm 0.11^{\mathrm{b}}$ \\
\hline
\end{tabular}

${ }^{\mathrm{a}, \mathrm{b}}$ Means $\pm \mathrm{SD}$ (of 2 trials) within a row and within casein type with no common superscript letters differ $(P$ $<0.05)$.

${ }^{1}$ Results are expressed as a percentage of the $\alpha_{\mathrm{s}}$-CN and $\beta$-CN content present in the 15 -d-old cheese.

\section{Volatile Composition}

A total of 73 volatile compounds were identified in TRD and IND types of Beaten cheeses during $180 \mathrm{~d}$ of ripening (Tables 3 to 9). These compounds belong to different chemical families, including alcohols (16), esters (17), acids (14), terpenes (7), ketones (5), aldehydes (4), and miscellaneous (10). Identification of the volatile fraction has not been previously conducted in Macedonian Beaten cheese or in other cheeses where scalding of the curd is carried out in hot water. Esters, alcohols, and ketones were the most abundant compounds isolated in the headspace of Beaten cheeses. Some of the volatile compounds (17) were significantly influenced by production method and 30 compounds were significantly influenced by cheese age $(P<0.05)$.

Carboxylic Acids. Fourteen carboxylic acids were identified in the TRD and IND types of cheeses and their concentrations increased during ripening (Table 3). The principal acid was hexanoic acid and it was
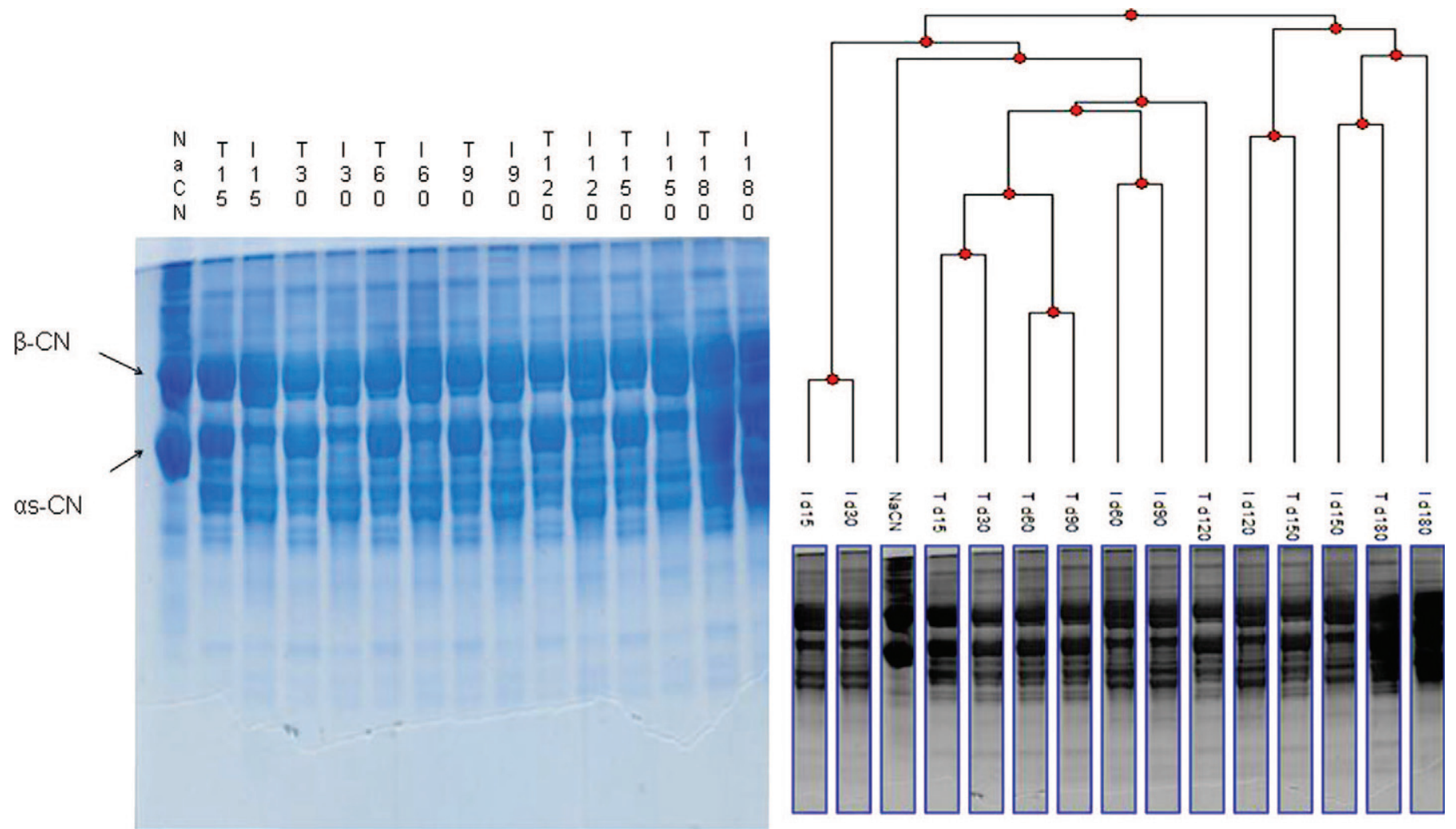

Figure 2. Left: urea-PAGE of the water-insoluble fractions of Beaten ewe milk cheeses made using traditional (T) or industrial (I) methods during $180 \mathrm{~d}$ of ripening. Right: hierarchical cluster analysis of the bands by ImageMaster TotalLab Phoretix 1D Pro software (Keel House, Newcastle upon Tyne, UK). Color version available in the online PDF. 
a)

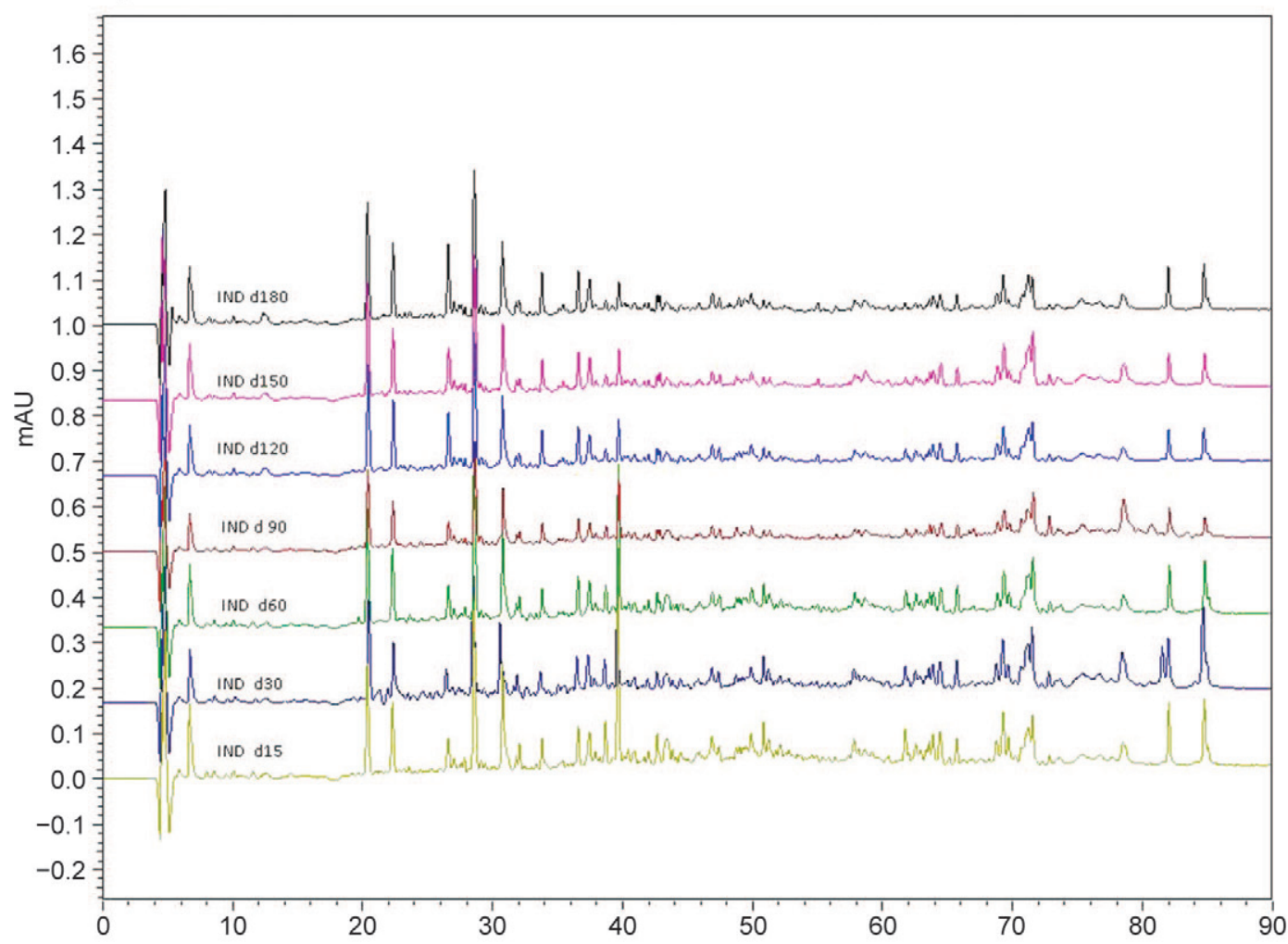

b)

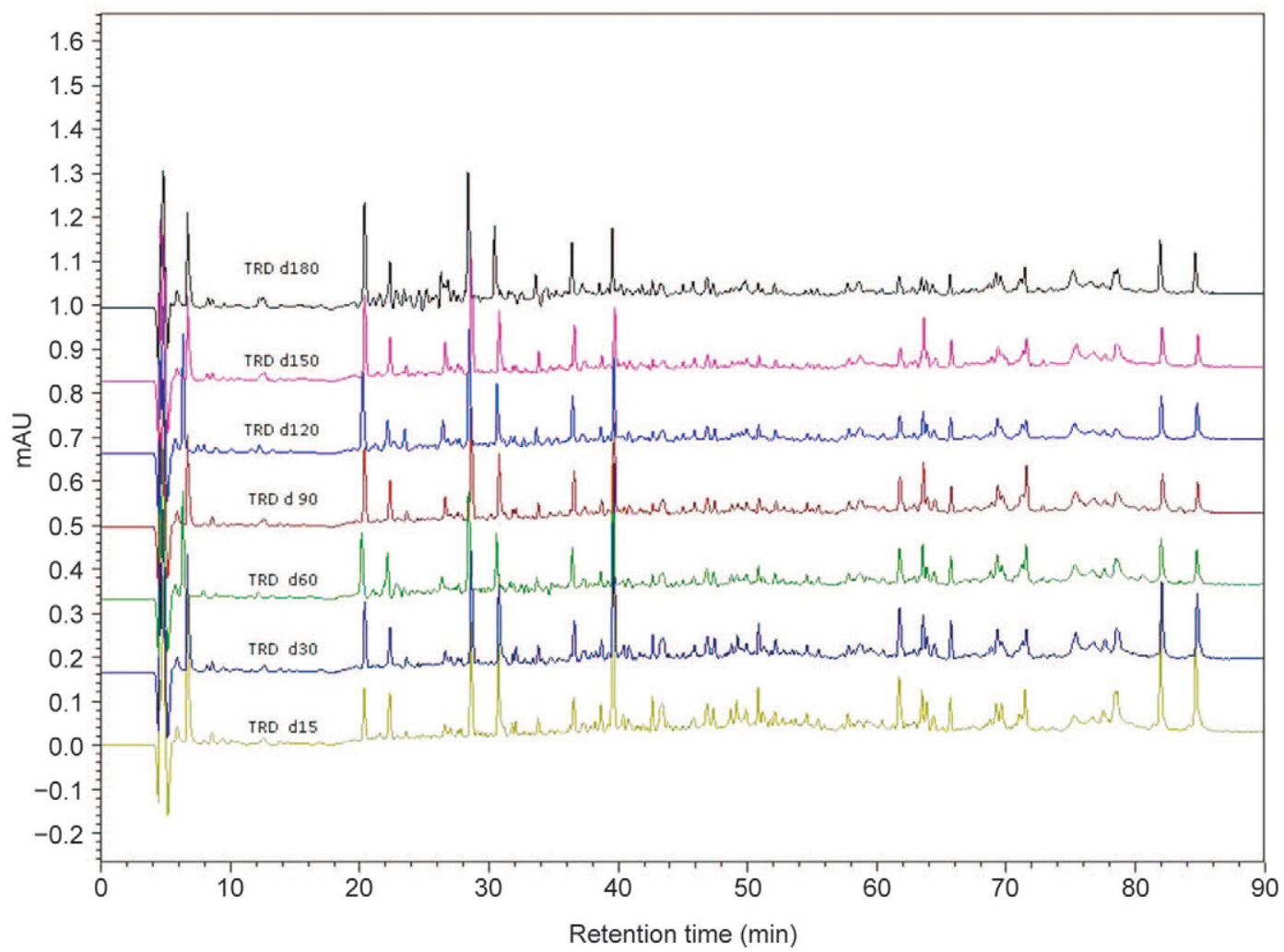

Figure 3. Reversed-phase HPLC profiles of the water-soluble fraction of industrial (IND; a) and traditional (TRD; b) Beaten ewe milk cheese. Detection was at $214 \mathrm{~nm} . \mathrm{mAU}=$ milliabsorbance units. Color version available in the online PDF. 
identified at higher levels in IND cheese samples during ripening. Hexanoic acid is produced by lipolysis and it contributes significantly to goat cheese odor (Hayaloglu et al., 2013). It has been identified as the main odorant in different cheese types, such as aged Cheddar (Christensen and Reineccius, 1995), Grana Padano (Moio and Addeo, 1998), and Gokceada goat cheese (Hayaloglu et al., 2013). The other major acid was butanoic acid, which has a rancid cheese-like odor and plays an important role in the flavor of many types of cheeses, such as Camembert, Cheddar (aged, regular, and low fat), Grana Padano, Gruyère, Pecorino, Ragusano, and Roncal (Curioni and Bosset, 2002). At the end of ripening, all acids were at higher concentrations in IND cheeses compared with TRD cheeses. Butanoic and acetic acids were significantly affected by manufacturing method, and also very abundant in IND cheese samples. Acetic and pentanoic acids could be responsible for the slightly sour taste of Beaten cheese. Heptanoic, octanoic, and decanoic acids were also presented at substantial levels in the 2 types of Beaten cheeses. Acetic acid is found in other brine-ripened cheeses manufactured in Turkey (Hayaloglu and Karabulut, 2013), and also in Spanish Torta del Casar cheese made of ewe milk (Delgado et al., 2010). Acetic acid was detected at a higher concentration $(1,316 \mu \mathrm{g} / 100 \mathrm{~g})$ in IND Beaten cheeses at $\mathrm{d}$ 180 of ripening; its concentration in TRD Beaten cheese was $732 \mu \mathrm{g} / 100 \mathrm{~g}$. Other carboxylic acids detected in Beaten cheese are listed in Table 3; it was thought that these acids contributed to the characteristic acid taste of Beaten cheese.

Esters. The volatile profile of ewe cheeses is characterized by the presence of ethyl esters (mainly ethyl acetate, ethyl butanoate, and ethyl octanoate). Esters are common cheese volatiles described as having sweet, fruity, and floral notes. Ethyl esters are particularly known for their important role in the formation of the fruity aroma in cheese (Curioni and Bosset, 2002). Esters were the unique chemical family that increased during ripening (Table 4), probably due to the esterification

Table 3. Abundance of carboxylic acids ( $\mu \mathrm{g} / 100 \mathrm{~g}$ of cheese; mean $\pm \mathrm{SD}$ ) in traditional (TRD) and industrial (IND) Beaten cheeses during ripening

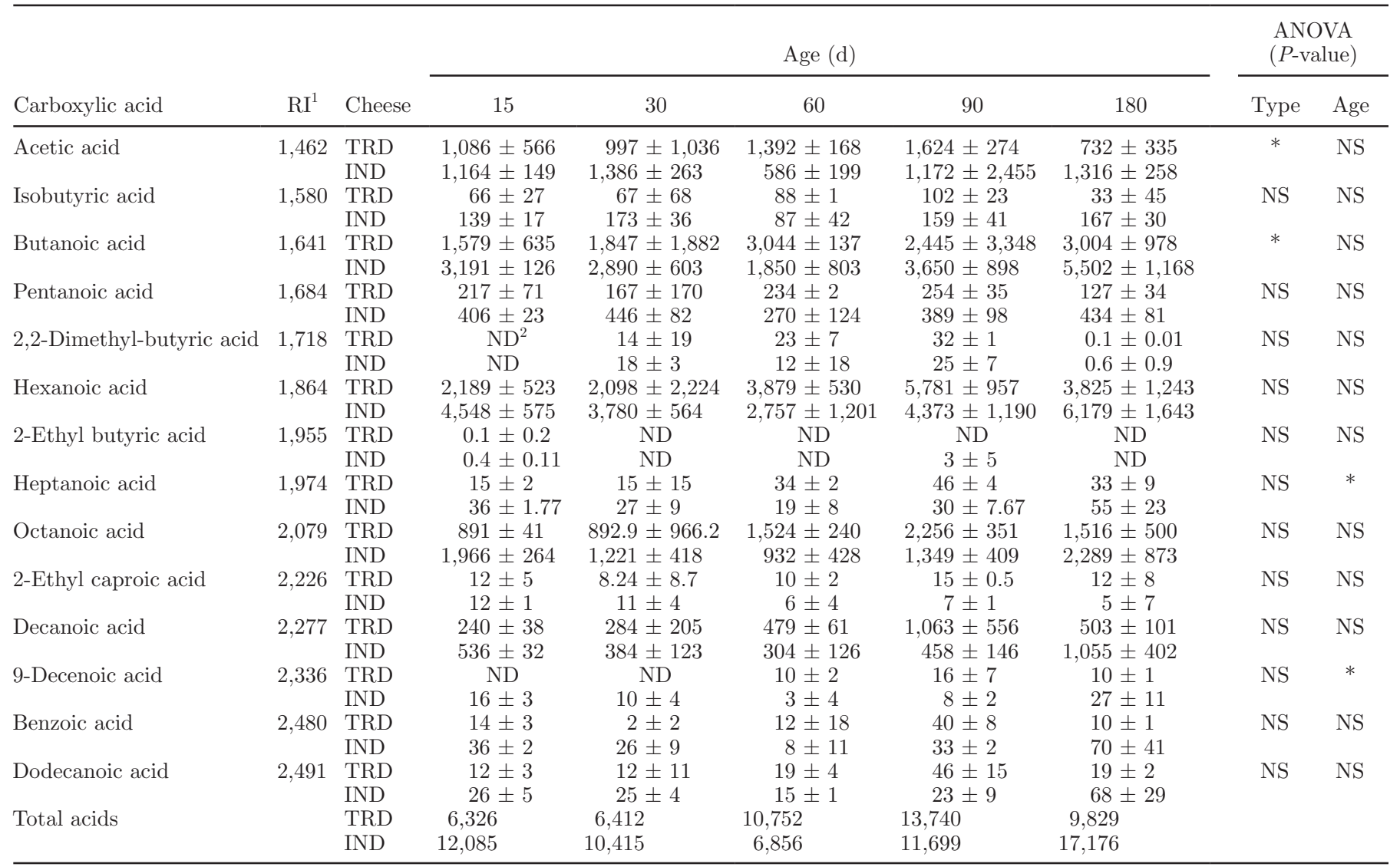

${ }^{1} \mathrm{RI}=$ retention index using alkane series (C8 to C20) under the same chromatographic conditions.

${ }^{2} \mathrm{ND}=$ not detected.

$* P<0.05$. 
reactions between acids and alcohols. The abundance of methyl pentanoate and isoamyl acetate was significantly affected by manufacturing method (Table 4). Methyl esters decreased significantly during the aging period and they were the most abundant esters isolated from IND Beaten cheeses. Ethyl esters are considered very important in other ewe cheeses (Izco and Torre, 2000; Larráyoz et al., 2001; Di Cagno et al., 2003). According to the available literature, ewe cheeses contain higher amounts of esters and FFA (Carbonell et al., 2002).

Alcohols. Alcohols are the main chemical family in some ewe milk cheeses, where ethanol, in terms of quantity, is the most important one (Carbonell et al., 2002; Kondyli et al., 2002; Bintsis and Robinson, 2004). Alcohols were one of the principal chemical groups in Beaten cheese volatiles and they probably had an influence on the flavor of the cheese. The abundances of 1-penten-3-ol and 1-hexanol from primary alcohols were significantly affected by different heat treatment of the curd (Table 5). The relative abundance of ethanol was significantly decreased at the end of ripening. Ethanol can be derived from amino acid catabolism (Strecker degradation of alanine), or from ethanal reduction (Molimard and Spinnler, 1996). Furthermore, ethanol is the precursor of ethyl esters, volatile compounds relevant to cheese aroma (Molimard and Spinnler, 1996). Lower heat treatment of the curd on the first day of ripening in IND cheeses may cause an increase in the levels of total FAA (Table 1), one of the precursors of ethanol by Strecker degradation, which explains the highest levels of ethanol found in IND cheeses at all ripening stages. A very high abundance of 3-methyl-1-butanol was found in TRD cheeses at d 60 of ripening (Table 5). Other branched alcohols (except 2-ethyl-1-hexanol)

Table 4. Abundance of esters ( $\mu \mathrm{g} / 100 \mathrm{~g}$ of cheese; mean $\pm \mathrm{SD}$ ) in traditional (TRD) and industrial (IND) Beaten cheeses during ripening

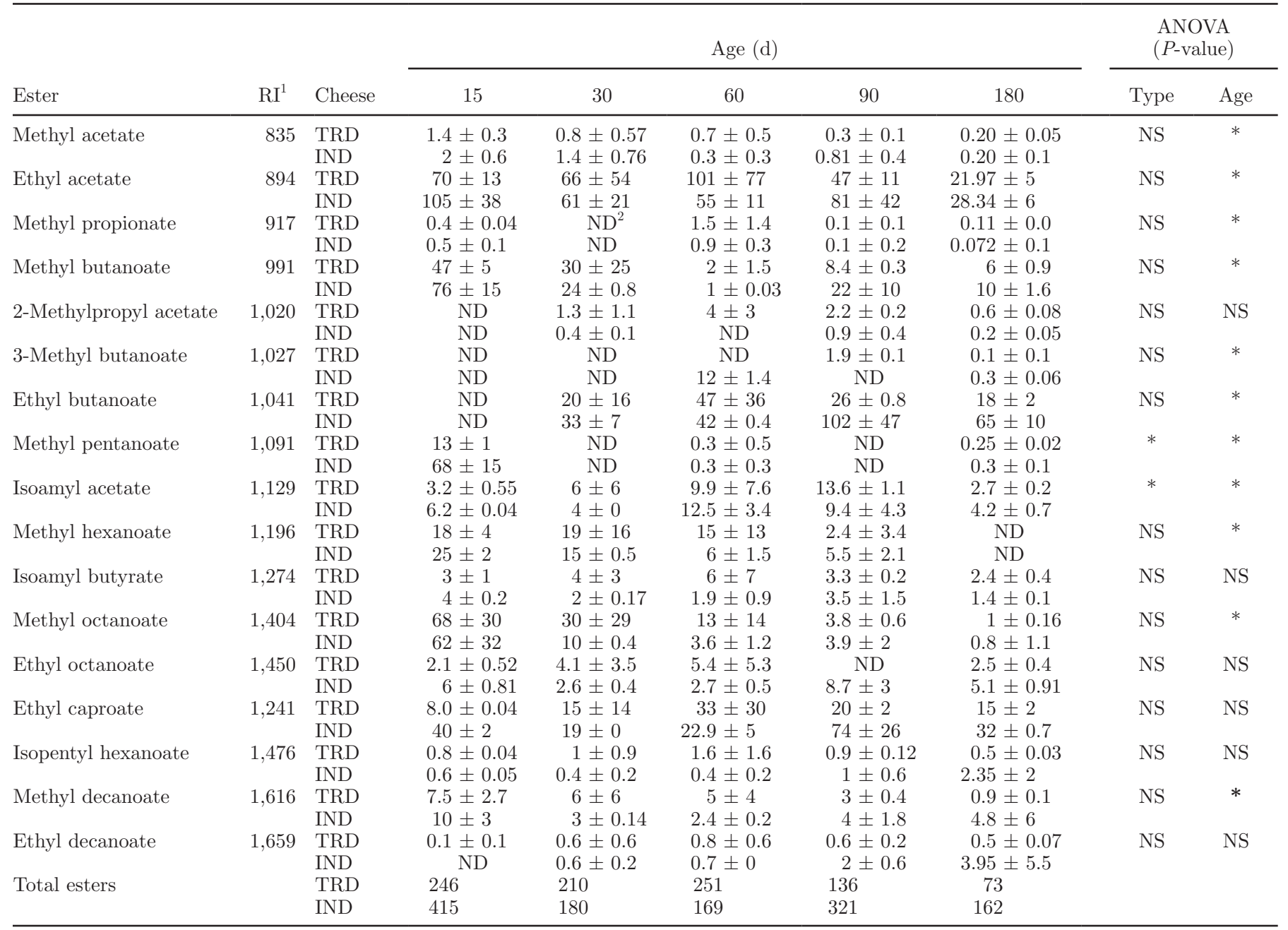

${ }^{1} \mathrm{RI}=$ retention index using alkane series (C8 to C20) under the same chromatographic conditions.

${ }^{2} \mathrm{ND}=$ not detected.

$* P<0.05$. 
Table 5. Abundance of alcohols ( $\mu \mathrm{g} / 100 \mathrm{~g}$ of cheese; mean $\pm \mathrm{SD}$ ) in traditional (TRD) and industrial (IND) Beaten cheeses during ripening

\begin{tabular}{|c|c|c|c|c|c|c|c|c|c|}
\hline \multirow[b]{2}{*}{ Alcohol } & \multirow[b]{2}{*}{$\mathrm{RI}^{1}$} & \multirow[b]{2}{*}{ Cheese } & \multicolumn{5}{|c|}{ Age (d) } & \multicolumn{2}{|c|}{$\begin{array}{c}\text { ANOVA } \\
(P \text {-value })\end{array}$} \\
\hline & & & 15 & 30 & 60 & 90 & 180 & Type & Age \\
\hline \multirow{2}{*}{ 1-Butanol } & 1,155 & TRD & $0.4 \pm 0.57$ & $1 \pm 1$ & $0.9 \pm 0.9$ & $0.5 \pm 0.1$ & $\mathrm{ND}^{2}$ & NS & NS \\
\hline & & IND & $1.1 \pm 0.16$ & $0.8 \pm 0.2$ & $0.6 \pm 0.05$ & $1.3 \pm 0.5$ & $0.3 \pm 0.07$ & & \\
\hline 1-Pentanol & & IND & $0.3 \pm 0.4$ & $3 \pm 0$ & $0.4 \pm 0.6$ & ND & $1 \pm 1$ & & \\
\hline \multirow[t]{2}{*}{ 1-Hexanol } & 1,359 & TRD & $0.7 \pm 0.01$ & $1.1 \pm 1$ & $2.4 \pm 1.9$ & $1.1 \pm 0.1$ & $0.2 \pm 0.3$ & * & NS \\
\hline & & IND & $0.2 \pm 0.2$ & $0.42 \pm 0.05$ & ND & ND & $0.2 \pm 0.05$ & & \\
\hline \multirow[t]{2}{*}{ 2-Phenethyl alcohol } & 1,947 & TRD & $5 \pm 2$ & $4 \pm 4$ & $6 \pm 5$ & $4 \pm 0.9$ & $1 \pm 0.05$ & NS & NS \\
\hline & & IND & $13 \pm 2$ & $7.9 \pm 0.1$ & $9 \pm 0.09$ & $10 \pm 4$ & $17 \pm 14$ & & \\
\hline 2-Propanol & 882 & TRD & ND & $1.71 \pm 2$ & ND & ND & ND & * & * \\
\hline \multirow[t]{2}{*}{ 2-Pentanol } & 1,122 & TRD & $0.2 \pm 0.03$ & $0.3 \pm 0.3$ & $0.4 \pm 0.6$ & $0.3 \pm 0.01$ & $0.1 \pm 0.02$ & NS & NS \\
\hline & & IND & $1.1 \pm 0.14$ & $0.6 \pm 0.1$ & $0.7 \pm 0.1$ & $1.4 \pm 0.6$ & $0.6 \pm 0.1$ & & \\
\hline \multirow[t]{2}{*}{ 2-Heptanol } & 1,323 & TRD & $0.7 \pm 0.04$ & $0.6 \pm 0.5$ & $1.11 \pm 0.8$ & ND & $0.3 \pm 0.05$ & NS & NS \\
\hline & & IND & $0.8 \pm 0.004$ & $0.2 \pm 0.4$ & $0.5 \pm 0.1$ & $0.88 \pm 0.4$ & $0.7 \pm 0.1$ & & \\
\hline \multirow{2}{*}{ 2-Pentanol } & 1,352 & TRD & ND & $0.5 \pm 0.7$ & ND & ND & $0.04 \pm 0.07$ & NS & NS \\
\hline & & IND & ND & $0.2 \pm 0.3$ & ND & ND & $0.3 \pm 0.007$ & & \\
\hline \multirow{2}{*}{ 3-Methyl-1-butanol } & 1,214 & TRD & $85 \pm 20$ & $74 \pm 10$ & $194 \pm 172$ & $106 \pm 7$ & $46 \pm 9$ & NS & * \\
\hline & & IND & $95 \pm 48$ & $46 \pm 11$ & $78 \pm 22$ & $105 \pm 50$ & $36 \pm 4$ & & \\
\hline \multirow[t]{2}{*}{ 3-Methyl-2-buten-1-ol } & 1,327 & TRD & $0.4 \pm 0.1$ & $0.4 \pm 0.3$ & $0.7 \pm 0.5$ & $0.33 \pm 0.01$ & $0.2 \pm 0.01$ & NS & NS \\
\hline & & IND & $0.8 \pm 0.03$ & $0.3 \pm 0.4$ & $0.5 \pm 0.1$ & $1.16 \pm 0.5$ & $0.5 \pm 0.09$ & & \\
\hline \multirow[t]{2}{*}{ 2-Methyl-3-hexanol } & 1,380 & TRD & ND & $0.1 \pm 0.1$ & $0.5 \pm 0.2$ & $0.19 \pm 0.07$ & $0.1 \pm 0.02$ & NS & NS \\
\hline & & IND & ND & ND & ND & $0.1 \pm 0.18$ & $0.4 \pm 0.02$ & & \\
\hline \multirow[t]{2}{*}{2 Ethyl-1-hexanol } & 1,498 & TRD & ND & $0.2 \pm 0.2$ & $0.2 \pm 0.39$ & ND & ND & * & NS \\
\hline & & IND & ND & ND & $0.05 \pm 0.08$ & ND & ND & & \\
\hline
\end{tabular}

${ }^{1} \mathrm{RI}=$ retention index using alkane series (C8 to C20) under the same chromatographic conditions.

${ }^{2} \mathrm{ND}=$ not detected.

$* P<0.05$.

were not significantly affected by the heat treatment of the curd.

Methyl Ketones. A total of 5 ketones were identified in both Beaten cheeses. 2-Butanone and 3-hydroxy2-butanone (acetoin) identified in Beaten cheeses and some ketones were significantly affected by the manufacturing method of Beaten cheese. The concentrations of methyl ketones increased during the first $60 \mathrm{~d}$ of ripening and then decreased rapidly (Table 6). This decline was probably due to the decrease in microbial activity during ripening, as the FFA arising from lipolysis are generally catabolized to methyl ketones by microorganisms (Barbieri et al., 1994). Methyl ketones are produced from FFA by an alternative pathway to the $\beta$-oxidation of FA (McSweeney and Sousa, 2000). 2-Butanone, which has a butterscotch odor, was identified as the main odorant in Cheddar cheese (Arora et al., 1995) and 2-heptanone, which has a herbaceous odor, is an important flavor compound of Emmental and natural and creamy Gorgonzola cheeses (Curioni and Bosset, 2002). A larger amount of 2-butanone was determined in IND cheese than in TRD cheese at the end of ripening. Similar results were found in other regional raw milk cheeses with Protected Designation of Origin (PDO) in Spain (Carbonell et al., 2002; Delgado et al., 2010), so they can play an important role in the final aroma of these cheeses made using raw milk.

Aldehydes. Aldehydes are commonly found in the volatile profiles of ewe cheeses and, within this group, 3-methyl-1-butanal is considered to be the typical and important compound (Larráyoz et al., 2001; Carbonell et al., 2002; Kondyli et al., 2002). At d 60 of ripening, the abundance of aldehydes in IND cheeses was lower than in TRD cheeses, but afterward, these compounds tended to increase in IND cheeses, showing the highest levels at d 180 of ripening (Table 7). No significant 
Table 6. Abundance of methyl ketones $(\mu \mathrm{g} / 100 \mathrm{~g}$ of cheese; mean $\pm \mathrm{SD}$ ) in traditional (TRD) and industrial (IND) Beaten cheeses during ripening

\begin{tabular}{|c|c|c|c|c|c|c|c|c|c|}
\hline Ketone & $\mathrm{RI}^{1}$ & Cheese & \multicolumn{5}{|c|}{ Age (d) } & \multicolumn{2}{|c|}{ ANOVA ( $P$-value $)$} \\
\hline 2-Propanone (acetone) & & IND & $6 \pm 3$ & $3 \pm 1$ & $2 \pm 0.2$ & $4 \pm 2$ & $1 \pm 1$ & & \\
\hline \multirow[t]{2}{*}{ 2-Butanone } & 907 & TRD & $3 \pm 1$ & $2 \pm 2$ & $6 \pm 4$ & $5 \pm 1$ & $2 \pm 1$ & $*$ & NS \\
\hline & & IND & $10 \pm 4$ & $3 \pm 1$ & $7 \pm 2$ & $24 \pm 13$ & $14 \pm 4$ & & \\
\hline 2-Pentanone & 982 & TRD & $13 \pm 2$ & $19 \pm 16$ & $29 \pm 23$ & $16 \pm 1$ & $8 \pm 1$ & NS & NS \\
\hline 2-Heptanone & & IND & $5 \pm 0$ & $6 \pm 1$ & $4 \pm 0.9$ & $9 \pm 3$ & $5 \pm 1$ & & \\
\hline \multirow[t]{2}{*}{ 3-Hydroxy-2-butanone } & 1,298 & TRD & $40 \pm 9$ & $42 \pm 37$ & $60 \pm 43$ & $32 \pm 2$ & $14 \pm 0$ & $*$ & NS \\
\hline & & IND & $2 \pm 0$ & $2 \pm 0$ & $2 \pm 0$ & $5 \pm 2$ & $3 \pm 1$ & & \\
\hline \multirow[t]{2}{*}{ Total ketones } & & TRD & 65 & 76 & 113 & 63 & 30 & & \\
\hline & & IND & 34 & 27 & 26 & 67 & 30 & & \\
\hline
\end{tabular}

${ }^{1} \mathrm{RI}=$ retention index using alkane series (C8 to C20) under the same chromatographic conditions.

$* P<0.05$.

differences in concentrations of hexanal, 2-methyl1-butanal, 3-methyl-1-butanal, and benzaldehyde were found in the cheeses, regardless whether they were manufactured according to the IND or TRD method. Straight-chain aldehydes, such as hexanal, may be formed by $\beta$-oxidation of unsaturated FA and are characterized by green-grass and herbaceous aromas. On d 60 of ripening, a lower abundance of hexanal was detected in IND cheeses. In spite of their low concentrations, some aldehydes have low perception thresholds and may play an important role in the cheese aroma (Izco and Torre, 2000; Bintsis and Robinson, 2004). Branched-chain aldehydes, such as 2-methyl-1-butanal and 3-methyl-1-butanal, originate from isoleucine and leucine, respectively, by Strecker degradation (McSweeney and Sousa, 2000).

Terpenes. Seven terpenes were detected in Beaten cheese and D-limonene was the principal terpene in the cheese (Table 8). At d 15 of ripening, the abundance of D-limonene in IND cheeses was higher than in TRD cheeses, but afterward, this compound was not detected after $90 \mathrm{~d}$ of ripening. 1,3-Octadiene, $\beta$-myrcene, sabinene, and $p$-cymene were significantly affected by the manufacturing method. Terpenes presumably come from animal forage (Carbonell et al., 2002); therefore, these are important for determining the geographical origin of a cheese type (Dunn and Lindsay, 1985).

Miscellaneous Compounds. A total of 10 miscellaneous compounds were detected in Beaten cheese during ripening. Some of them were hydrocarbons that originated from lipid oxidation (Carbonell et al., 2002). It has been reported that a wide number of hydrocarbons were isolated in Grana cheeses, but they did not contribute significantly to the aroma (Barbieri et al., 1994). Hexane and toluene, which are hydrocarbons, were identified at higher levels compared with others in this group, and their concentrations decreased significantly during ripening (Table 9). With regard to the

Table 7. Abundance of aldehydes ( $\mu \mathrm{g} / 100 \mathrm{~g}$ of cheese; mean $\pm \mathrm{SD}$ ) in traditional (TRD) and industrial (IND) Beaten cheeses during ripening

\begin{tabular}{|c|c|c|c|c|c|c|c|c|c|}
\hline Aldehyde & $\mathrm{RI}^{1}$ & Cheese & \multicolumn{5}{|c|}{ Age (d) } & \multicolumn{2}{|c|}{ ANOVA ( $P$-value) } \\
\hline Hexanal & 747 & $\begin{array}{l}\text { TRD } \\
\text { IND }\end{array}$ & $\begin{array}{l}0.7 \pm 0 \\
0.4 \pm 0\end{array}$ & $\begin{array}{l}0.3 \pm 0 \\
0.4+06\end{array}$ & $\begin{array}{l}1.5 \pm 1.7 \\
0.3+0\end{array}$ & $\mathrm{ND}^{2}$ & $\begin{array}{r}0.8 \pm 0 \\
1+0\end{array}$ & NS & $*$ \\
\hline 2-Methyl-1-butanal & 919 & $\begin{array}{l}\text { TRD } \\
\text { IND }\end{array}$ & $\begin{array}{l}\text { ND } \\
\text { ND }\end{array}$ & $\begin{array}{l}.4 \pm 0.0 \\
\text { ND } \\
\text { ND }\end{array}$ & $\begin{array}{l}0.3 \pm 0 \\
0.3 \pm 0 \\
0.7 \pm 1\end{array}$ & $\begin{array}{l}\text { ND } \\
\text { ND }\end{array}$ & $\begin{array}{c}1 \pm 0 \\
0.06 \pm 0 \\
\mathrm{ND}\end{array}$ & NS & $*$ \\
\hline 3-Methyl-1-butanal & 923 & $\begin{array}{l}\text { TRD } \\
\text { IND }\end{array}$ & $\begin{array}{l}2 \pm 0 \\
2 \pm 1\end{array}$ & $\begin{array}{l}1 \pm 1 \\
1 \pm 0.4\end{array}$ & $\begin{array}{l}36 \pm 26 \\
24 \pm 2\end{array}$ & $\begin{array}{l}1 \pm 0 \\
2 \pm 1\end{array}$ & $\begin{array}{l}0.7 \pm 0 \\
2.1 \pm 0\end{array}$ & NS & $*$ \\
\hline
\end{tabular}

${ }^{1} \mathrm{RI}=$ retention index using alkane series (C8 to C20) under the same chromatographic conditions.

${ }^{2} \mathrm{ND}=$ not detected.

$* P<0.05$. 
Table 8. Abundance of terpenes ( $\mu \mathrm{g} / 100 \mathrm{~g}$ of cheese; mean $\pm \mathrm{SD}$ ) in traditional (TRD) and industrial (IND) Beaten cheeses during ripening

\begin{tabular}{|c|c|c|c|c|c|c|c|c|c|}
\hline Terpene & $\mathrm{RI}^{1}$ & Cheese & \multicolumn{5}{|c|}{ Age (d) } & \multicolumn{2}{|c|}{ ANOVA ( $P$-value) } \\
\hline 1.3-Octadiene & 963 & $\begin{array}{l}\text { TRD } \\
\text { IND }\end{array}$ & $\begin{array}{l}\mathrm{ND}^{2} \\
\mathrm{ND}\end{array}$ & $\begin{array}{c}\mathrm{ND} \\
1.2 \pm 0\end{array}$ & $\begin{array}{l}0.3 \pm 0 \\
0.2 \pm 0\end{array}$ & $\begin{array}{c}0.4 \pm 0 \\
\mathrm{ND}\end{array}$ & $\begin{array}{r}0.2 \pm 0 \\
1 \pm 2\end{array}$ & * & NS \\
\hline$\alpha$-Pinene & 1,027 & $\begin{array}{l}\text { TRD } \\
\text { IND }\end{array}$ & $\begin{array}{l}2.4 \pm 0 \\
1.4 \pm 2\end{array}$ & $\begin{array}{l}3.5 \pm 3 \\
2.6 \pm 0\end{array}$ & $\begin{array}{l}5 \pm 4 \\
1 \pm 1\end{array}$ & $\begin{array}{l}2 \pm 0 \\
4 \pm 2\end{array}$ & $\begin{array}{r}1 \pm 0 \\
2.1 \pm 0\end{array}$ & NS & NS \\
\hline 2- $\beta$-Pinene & 1,107 & $\begin{array}{l}\text { TRD } \\
\text { IND }\end{array}$ & $\begin{array}{l}0.2 \pm 0 \\
0.7 \pm 0\end{array}$ & $\begin{array}{l}0.4 \pm 0 \\
0.7 \pm 0\end{array}$ & $\begin{array}{l}0.8 \pm 0 \\
0.6 \pm 0\end{array}$ & $\begin{array}{l}0.2 \pm 0 \\
1.2 \pm 1\end{array}$ & $\begin{array}{l}0.1 \pm 0 \\
0.7 \pm 0\end{array}$ & NS & NS \\
\hline D-Limonene & 1,210 & $\begin{array}{l}\text { TRD } \\
\text { IND }\end{array}$ & $\begin{array}{l}14 \pm 19 \\
35 \pm 50\end{array}$ & $\begin{array}{l}72 \pm 88 \\
72 \pm 10\end{array}$ & $\begin{array}{c}36 \pm 14 \\
6 \pm 8\end{array}$ & $\begin{array}{l}\text { ND } \\
\text { ND }\end{array}$ & $\begin{array}{l}\text { ND } \\
\text { ND }\end{array}$ & NS & $*$ \\
\hline Sabinene & 1,121 & $\begin{array}{l}\text { TRD } \\
\text { IND }\end{array}$ & $\begin{array}{c}0.6 \pm 0 \\
\mathrm{ND}\end{array}$ & $\begin{array}{l}\text { ND } \\
\text { ND }\end{array}$ & $\begin{array}{l}0.7 \pm 0 \\
0.4 \pm 0\end{array}$ & $\begin{array}{l}\text { ND } \\
\text { ND }\end{array}$ & $\begin{array}{l}\text { ND } \\
\text { ND }\end{array}$ & $*$ & $*$ \\
\hline$p$-Cymene & 1,282 & $\begin{array}{l}\text { TRD } \\
\text { IND }\end{array}$ & $\begin{array}{l}1.5 \pm 0 \\
0.9 \pm 0\end{array}$ & $\begin{array}{l}0.4 \pm 0 \\
0.2 \pm 0\end{array}$ & 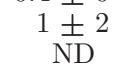 & $\begin{array}{l}\text { ND } \\
\text { ND }\end{array}$ & $\begin{array}{l}\text { ND } \\
\text { ND }\end{array}$ & * & NS \\
\hline
\end{tabular}

${ }^{1} \mathrm{RI}=$ retention index using alkane series $(\mathrm{C} 8$ to $\mathrm{C} 20)$ under the same chromatographic conditions.

${ }^{2} \mathrm{ND}=$ not detected.

$* P<0.05$.

aromatic hydrocarbons, toluene, which provides nutty odor, was the most abundant and already identified at high levels in Feta-type (Bintis and Robinson, 2004) and Spanish ewe milk semi-hard cheeses (Mariaca et al., 2001). Xylene most probably originates from forage, whereas benzyl compounds could derive from the degradation of carotene in the milk (Hayaloglu and Karabulut, 2013).

\section{Texture in Cheese}

The texture of Beaten cheese was analyzed during the $180 \mathrm{~d}$ of ripening and the results showed that the most pronounced effect of maturation was observed in hardness values (Figure 4). Proteolysis appears as a main factor responsible for the differences in texture between TRD and IND cheeses. The hardness values decreased by increasing the proteolysis level (see Figures 1 and 4). The increase in chymosin retention and plasmin activity by heat treatment of cheese curd may be the main reason for the differences between TRD and IND cheeses. The texture characteristics are attributed mostly to proteolysis differences in which enzymes such as chymosin or plasmin have a great influence (Shakeel-Ur-Rehman et al., 2000). The TRD cheeses were firmer than IND cheeses during ripening. This is due to the high cooking temperature in TRD cheeses, which also increases the firmness and lowers the moisture content of the curds (Emmons and Beckett, 1984). These characteristics were attributed to the levels of moisture and WSN; when moisture is lower, caseins are more intact. The breakage stress was higher in TRD cheeses (i.e., less breakable than IND cheeses). This parameter has the same correlation with moisture and WSN as mentioned above (i.e., deformability decreases when the hydration of proteins decreases and elastic structural elements disappear; Buffa et al., 2001).

\section{CONCLUSIONS}

Two types of Macedonian Beaten ewe milk cheeses were manufactured with IND and TRD methods and the cheeses were well characterized regarding the chemical composition, total FAA, peptide profiles, textural characteristics, and volatile compounds during ripening. The TRD cheeses, made with a raw milk and higher scalding temperature, were characterized by higher TS, fat, and protein contents. Low levels of proteolysis in

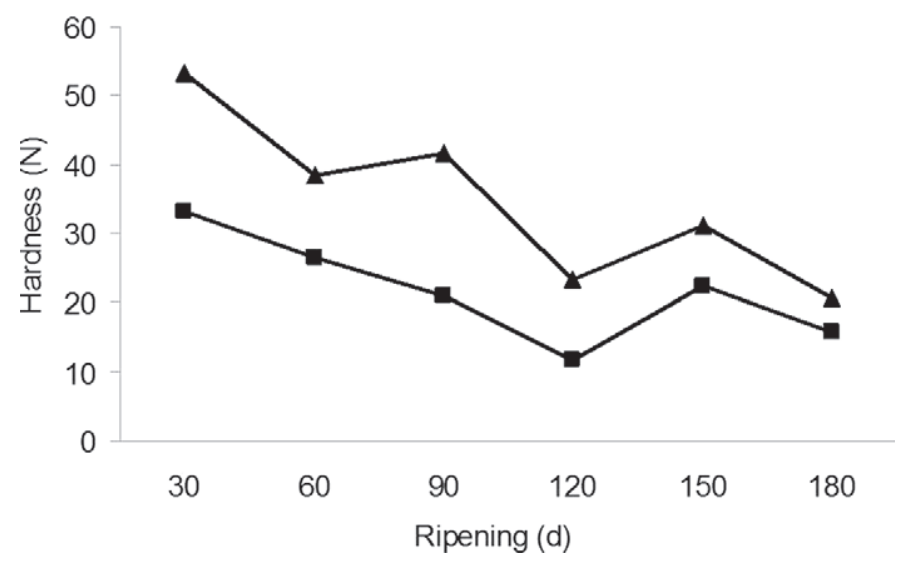

Figure 4. Hardness values (N) of traditional (TRD; triangles) and industrial (IND; squares) Beaten cheese during ripening. 
Table 9. Abundance of miscellaneous compounds ( $\mu \mathrm{g} / 100 \mathrm{~g}$ of cheese; mean $\pm \mathrm{SD}$ ) in traditional (TRD) and industrial (IND) Beaten cheeses during ripening

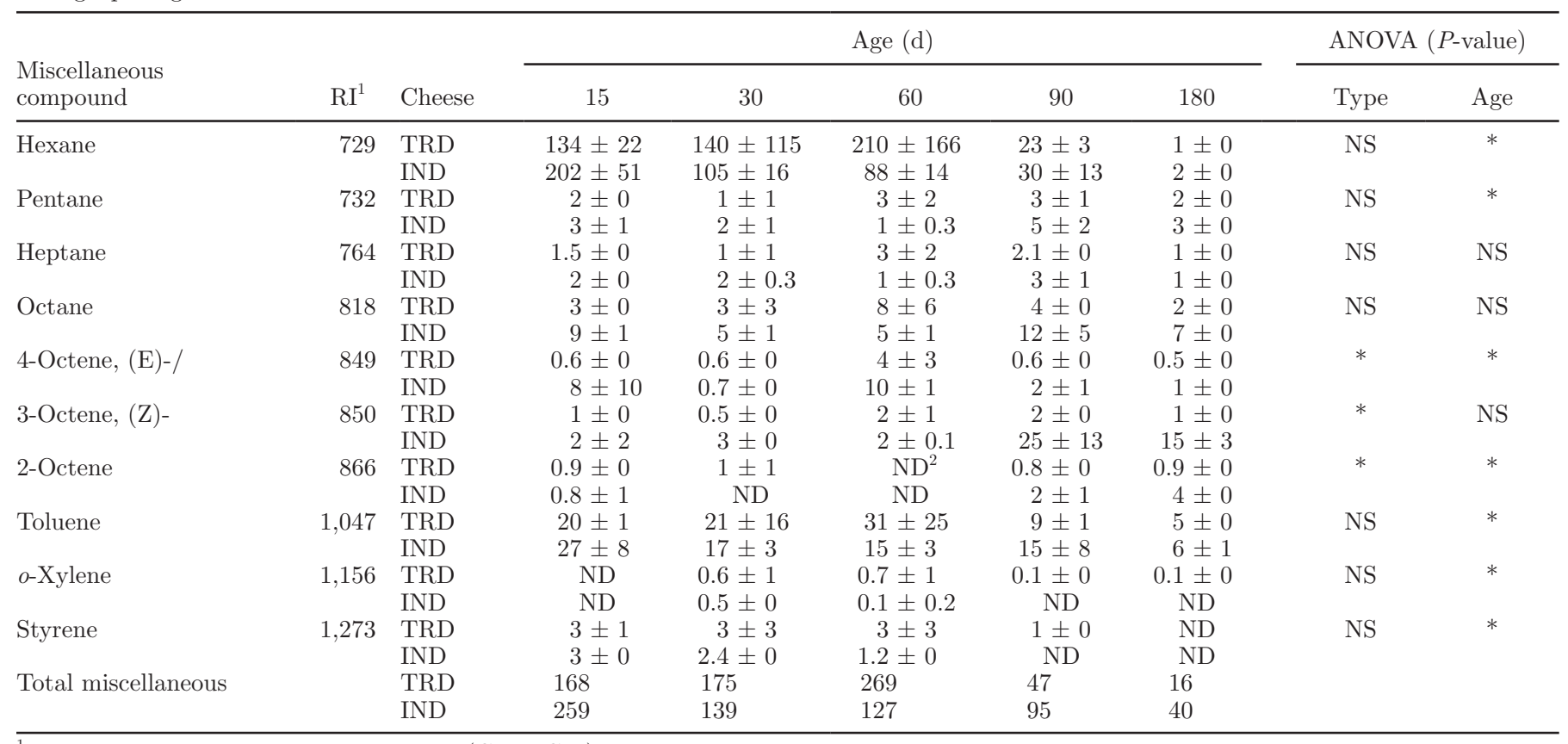

${ }^{1} \mathrm{RI}=$ retention index using alkane series (C8 to $\left.\mathrm{C} 20\right)$ under the same chromatographic conditions.

${ }^{2} \mathrm{ND}=$ not detected.

$* P<0.05$.

the cheeses; that is, lower casein breakdown and lower levels of WSN, 12\% TCA-SN, and total FAA, were observed when compared with the IND cheese. Moreover, TRD cheeses showed lower levels of the peptide fractions, which were mainly eluted between from 20 to 40 min. The TRD cheeses showed lower levels of the total contents of volatile compounds, including acids, alcohols, and esters than IND cheeses, which prevailed in the volatile profile of the IND cheeses. On the other hand, the application of lower scalding temperature and mechanization in IND cheeses produced a more noticeable proteolysis, and a greater production of volatile compounds. However, differences observed between the cheeses might be attributed to the differences in the natural microbiota of the cheeses. The IND cheeses resulted in a higher amount of total FAA than TRD cheeses. Moreover, IND cheeses showed the highest levels of volatile compounds at $180 \mathrm{~d}$ of ripening and lower levels in the hardness values during ripening compared with TRD cheeses. From the proteolysis, hardness, and volatiles results, the IND production method is recommended for the manufacture of Beaten cheese. These results are an important contribution to the better understanding of Macedonian Beaten ewe milk cheeses produced under IND and TRD methods. Also, they can help in the characterization and classification of cheeses based on volatile profiles, standardization of manufac- turing methods, and can encourage attempts to protect the geographical origin of the cheeses.

\section{ACKNOWLEDGMENTS}

Author E. Sulejmani is grateful to the Scientific and Technological Research Council of Turkey (TÜBİTAK, Ankara, Turkey) due to his fellowship under the 2216 program. The authors are grateful to the Chair of Scientific Research Projects Unit at İnönü University (Malatya, Turkey; project number 2012/34) for their financial support.

\section{REFERENCES}

Abd El-Salam, M. H., and E. Alichanidis. 2004. Cheeses varieties ripened in brine cheese. Pages 227-249 in Cheese Chemistry, Physics and Microbiology. Vol. 1. P. F. Fox, P. L. H. McSweeney, T. M. Cogan, and T. P. Guinee, ed. Elsevier Academic Press, London, UK.

Alichanidis, E., and A. Polychroniadou. 2008. Characteristics of major traditional regional cheese varieties of East-Mediterranean countries: A review. Dairy Sci. Technol. 88:495-510.

Andiç, S., H. Gençcelep, Y. Tunçtürk, and S. Köse. 2010. The effect of storage temperatures and packaging methods on properties of Motal cheese. J. Dairy Sci. 93:849-859.

Andrews, A. T. 1983. Proteinases in normal bovine milk and their action on caseins. J. Dairy Res. 50:45-55.

Ardö, Y., and A. Polychroniadou. 1999. Laboratory Manual for Chemical Analysis of Cheese. Publications Office of the European Communities, Luxembourg. 
Arora, G., E. Cormier, and B. Lee. 1995. Analysis of odor active volatiles in Cheddar cheese headspace by multidimensional GC/MS/ sniffing. J. Agric. Food Chem. 43:748-752.

Barbieri, G., L. Bolzoni, M. Careri, A. Mangia, G. Parolari, S. Spagnoli, and R. Virgili. 1994. Study of the volatile fraction of Parmesan cheese. J. Agric. Food Chem. 42:1170-1176.

Bintsis, T., and R. K. Robinson. 2004. A study of the effects of adjunct cultures on the aroma compounds of Feta-type cheese. Food Chem. 88:435-441.

Blakesley, R. W., and J. A. Boezi. 1977. A new staining technique for proteins in polyacrylamide gels using Coomassie brilliant blue G250. Anal. Biochem. 82:580-582.

Boudjellab, N., O. Rolet-Repecaud, and J.-C. Collin. 1994. Detection of residual chymosin in cheese by an enzyme-linked immunosorbent assay. J. Dairy Res. 61:101-109.

Buffa, M. N., A. J. Trujillo, M. Pavia, and B. Guamis. 2001. Changes in textural, microstructural, and colour characteristics during ripening of cheeses made from raw, pasteurized or high-pressuretreated goats' milk. Int. Dairy J. 11:927-934.

Bumberger, E., and H. D. Belitz. 1993. Bitter taste of enzymic hydrolysates of casein. I. Isolation, structural and sensorial analysis of peptides from tryptic hydrolysates of $\beta$-casein. Z. Lebensm. Unters. Forsch. 197:14-19.

Carbonell, M., M. Nuñez, and E. Fernández-García. 2002. Evolution of the volatile components of ewe raw milk La Serena cheese during ripening. Correlation with flavour characteristics. Lait 82:683698.

Christensen, K. R., and G. A. Reineccius. 1995. Aroma extract dilution analysis of aged Cheddar cheese. J. Food Sci. 60:218-220.

Curioni, P. M. G., and J. O. Bosset. 2002. Key odorants in various cheese types as determined by gas chromatography-olfactometry. Int. Dairy J. 12:959-984.

Delgado, F. J., J. González-Crespo, R. Cava, J. García-Parra, and R. Ramírez. 2010. Characterization by SPME-GC-MS of the volatile profile of a Spanish soft P.D.O. Torta del Casar during ripening. Food Chem. 118:182-189.

Di Cagno, R., J. Banks, L. Sheehan, P. F. Fox, E. Y. Brechany, A. Corsetti, and M. Gobbetti. 2003. Comparison of the microbiological, compositional, biochemical, volatile profile and sensory characteristics of three Italian PDO ewes' milk cheeses. Int. Dairy J. 13:961-972.

Dubrova Mateva, N., Z. Naletoski, and B. Palasevski. 2008. Technology and chemical composition of Beaten cheese in Republic of Macedonia. Biotechnol. Anim. Husband. 24:139-147.

Dubrova Mateva, N., and S. Srbinovska. 2010. Technological and chemical properties of traditional Bieno cheese in Macedonia. Page 290 in Proc. 1st International Symposium on "Traditional Foods from Adriatic to Caucasus." Namık Kemal University, Faculty of Agriculture, Department of Food Engineering, Tekirdağ, Turkey.

Dunn, J. C., and R. C. Lindsay. 1985. Evaluation of the role of microbial Strecker-derived aroma compounds in unclean-type flavors of Cheddar cheese. J. Dairy Sci. 68:2859-2874.

Emmons, D. B., and D. C. Beckett. 1984. Effect of gas-producing cultures on titratable acidity and $\mathrm{pH}$ in making Cottage cheese. J. Dairy Sci. 67:2192-2199.

Farkye, N. Y., and P. F. Fox. 1990. Observations on plasmin activity in cheese. J. Dairy Res. 57:413-418.

Fox, P. F., and J. M. Wallace. 1997. Formation of flavor compounds in cheese. Adv. Appl. Microbiol. 45:17-85.

Fox, P. F., and B. F. Walley. 1971. Influence of sodium chloride on the proteolysis of casein by rennet and by pepsin. J. Dairy Res. $38: 165-170$.

Frister, H., M. Michaelis, T. Schwerdtfeger, D. M. Folkenberg, and N. K. Sørensen. 2000. Evaluation of bitterness in Cheddar cheese. Milchwissenschaft 55:691-695.

Hayaloglu, A. A. 2007. Comparisons of different single strain starter cultures for their effects on ripening and grading of Beyaz cheese. Int. J. Food Sci. Technol. 42:930-938.

Hayaloglu, A. A., and E. Y. Brechany. 2007. Influence of milk pasteurization and scalding temperature on the volatile compounds of Malatya, a farmhouse Halloumi-type cheese. Lait 87:39-57.
Hayaloglu, A. A., K. C. Deegan, and P. L. H. McSweeney. 2010. Effect of milk pasteurization and curd scalding temperature on proteolysis in Malatya, a Halloumi-type cheese. Dairy Sci. Technol. 90:99-109.

Hayaloglu, A. A., M. Guven, P. F. Fox, and P. L. H. McSweeney, 2005. Influence of starters on chemical, biochemical, and sensory changes in Turkish White-brined cheese during ripening. J. Dairy Sci. 88:3460-3474.

Hayaloglu, A. A., and I. Karabulut. 2013. SPME/GC-MS characterization and comparison of volatiles of eleven varieties of Turkish cheeses. Int. J. Food Prop. 13:1630-1653.

Hayaloglu, A. A., C. Tolu, K. Yasar, and D. Sahingil. 2013. Volatiles and sensory evaluation of goat milk cheese Gokceada as affected by goat breeds (Gokceada and Turkish Saanen) and starter culture systems during ripening. J. Dairy Sci. 96:2765-2780.

Hayaloglu, A. A., A. Topcu, and N. Koca. 2011. Peynir analizleri [Cheese analysis]. Pages 489-562 in Peynir Biliminin Temeller Principles of Cheese Sciences), A. A. Hayaloglu, and B. Ozer, ed. Sidas, Izmir, Turkey.

IDF (International Dairy Federation). 1993. Milk. Determination of the nitrogen (Kjeldahl method) and calculation of the crude protein content. IDF Standard 20B. IDF, Brussels, Belgium.

Izco, J. M., and P. Torre. 2000. Characterisation of volatile flavour compounds in Roncal cheese extracted by the 'purge and trap' method and analysed by GC-MS. Food Chem. 70:409-417.

John Wiley and Sons Inc. 2005. Wiley Registry of Mass Spectral Data. 7th ed. F. W. McLafferty, ed. John Wiley and Sons Inc., Hoboken, NJ.

Karagul Yuceer, Y., B. Tuncel, O. Guneser, B. Engin, M. Isleten, K. Yasar, and M. Mendes. 2009. Characterization of aroma-active compounds, sensory properties, and proteolysis in Ezine cheese. J. Dairy Sci. 92:4146-4157.

Katsiari, M. C., E. Alichanidis, L. P. Voutsinas, and I. G. Roussis. 2000. Proteolysis in reduced sodium Feta cheese made by partial substitution of $\mathrm{NaCl}$ by KCl. Int. Dairy J. 10:635-646.

Kondyli, E., M. C. Katsiari, T. Masouras, and L. P. Voutsinas. 2002. Free fatty acids and volatile compounds of low fat Feta-type cheese made with a commercial adjunct culture. Food Chem. 79:199 205

Larráyoz, P., M. Addis, R. Gauch, and J. O. Bosset. 2001. Comparison of dynamic headspace and simultaneous distillation extraction techniques used for the analysis of the volatile components in three European PDO ewes' milk cheeses. Int. Dairy J. 11:911-926.

Mallatou, H., E. C. Pappa, and V. A. Boumba. 2004. Proteolysis in Teleme cheese made from ewes', goats' or a mixture of ewes' and goats' milk. Int. Dairy J. 14:977-987.

Mariaca, R. G., E. Fernández-García, A. F. Mohedano, and M. Nuñez. 2001. Volatile fraction of ewe's milk semi-hard cheese manufactured with and without the addition of a cysteine proteinase. Food Sci. Technol. Int. 7:131-139.

McSweeney, P. L. H. 2004. Biochemistry of cheese ripening: Introduction and overview. Pages 347-360 in Cheese: Chemistry, Physics and Microbiology: Volume 1: General Aspects. 3rd ed. P. F. Fox, P. L. H. McSweeney, T. M. Cogan, and T. P. Guinee ed. Elsevier Academic Press, London, UK.

McSweeney, P. L. H., and M. J. Sousa. 2000. Biochemical pathway for the production of flavour compounds in cheese during ripening. Lait 80:293-324.

Michaelidou-Koniordou, A. M. 1997. Protein hydrolysis during ripening of Feta cheese. PhD Thesis. Aristotle University of Thessaloniki, Thessaloniki, Greece.

Moio, L., and F. Addeo. 1998. Grana Padano cheese aroma. J. Dairy Res. 65:317-333.

Molimard, P., and H. E. Spinnler. 1996. Review: Compounds involved in the flavor of surface mold-ripened cheeses: Origins and properties. J. Dairy Sci. 79:169-184.

Papademas, P. 2000. Halloumi cheese: The product and its characteristics. PhD Thesis. School of Food Biosciences, University of Reading, Reading, UK.

Phelan, J. A., J. Guiney, and P. F. Fox. 1973. Proteolysis of $\beta$-casein in Cheddar cheese. J. Dairy Res. 40:105-112. 
Pinho, O., E. Mendes, M. M. Alves, and I. M. P. L. V. O. Ferreira. 2004. Chemical, physical, and sensorial characteristics of "Terrincho" ewe cheese: Changes during ripening and intravarietal comparison. J. Dairy Sci. 87:249-257.

Pintado, A. I. E., O. Pinho, M. P. L. V. O. Ferreira, M. M. E. Pintado, A. M. P. Gomes, and F. X. Malcata. 2008. Microbiological, biochemical and biogenic amine profiles of Terrincho cheese manufactured in several dairy farms. Int. Dairy J. 18:631-640.

SAS Institute. 1995. User's Guide: Statistics. Version 6. 12th ed. SAS Institute Inc., Cary, NC.

Shakeel-Ur-Rehman, J. M. Banks, P. L. H. McSweeney, and P. F. Fox. 2000. Effect of ripening temperature on the growth and signifi- cance of non-starter lactic acid bacteria in Cheddar cheese made from raw of pasteurized milk. Int. Dairy J. 10:45-53.

Swaisgood, H. E. 2003. Chemistry of the caseins. Pages 139-201 in Advanced Dairy Chemistry: Protein: Volume 1: Proteins, Part A. 3rd ed. P. F. Fox, and P. L. H. McSweeney, ed. Kluwer Academic/ Plenum Publishers, New York, NY.

Talevski, G. 2012. Traditional production of Beaten cheese. Pages 524-528 in Third International Scientific Symposium "Agrosym Jahorina 2012." Faculty of Agriculture, University of East Sarajevo, Republic of Srpska, Bosnia.. 